\title{
Transitivity Analysis of EFL Students' Narrative Text in Vocational High School
}

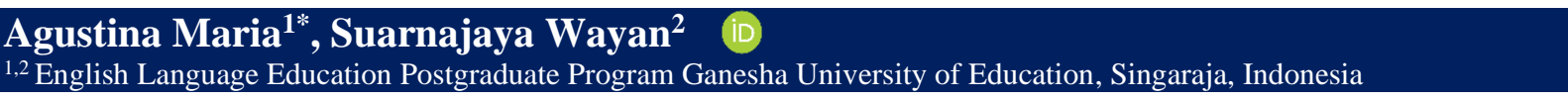

\section{A R T I C L E I N F O}

Article history:

Received August 08, 2021

Revised August 12, 2021

Accepted November 20, 202

Available online December 25, 2021

Kata Kunci:

Linguistik Fungsional Sistemik, Analisis Transitivitas, Teks Narasi

Keywords:

Systemic Functional Linguistics,

Transitivity Analysis, Narrative Text

DOI:

http://dx.doi.org/10.23887/jpbi.v9i3. $\underline{38314}$

\section{A B S T R A C T}

Language cannot be understood one at a time without considering contextual information about the current circumstances and culture. As a result, language can only be understood when individuals comprehend the circumstance and culture. This study aimed at identifying the process types that characterize the students' narrative texts. This study applied a descriptive qualitative method. The researcher collected the data from narrative texts. There were 28 students selected to be the subjects of this study. The collected data, presented in sentences and clauses, were analyzed using Halliday's transitivity system. Findings show that the process type that are dominantly used in the students' narrative texts are material, behavioral, intensive attributive, verbal, mental, and existential processes. The material process was the most common process type used because the students' subjects were connected to past figures. The findings in this study of the students' narrative texts demonstrate that the students must use the linguistic elements of a narrative text to give information. The purpose of text types in students' narrative texts is to encourage readers to imagine the words and sentence patterns used in the texts. It may help to minimize misunderstandings about the contents of the narrative text. As a result, while creating a narrative text, the students must employ the proper specific meaning, generic structure, linguistic characteristics, and language elements to stimulate readers' interest in providing necessary information while entertaining them.

This is an open-access article under the CC BY-SA license. Copyright (C) 2021 by Author. Published by Universitas Pendidikan Ganesha.

\begin{abstract}
Bahasa tidak dapat dipahami satu per satu tanpa mempertimbangkan informasi kontekstual tentang keadaan dan budaya saat ini. Akibatnya, bahasa hanya dapat dipahami ketika individu memahami keadaan dan budaya. Penelitian ini bertujuan menggunakan metode deskriptif kualitatif. Peneliti mengumpulkan data dari teks naratif. Ada 28 siswa yang dipilih menjadi subjek penelitian ini. Data yang terkumpul, disajikan dalam kalimat dan klausa, dianalisis menggunakan sistem transitivitas eksistensial. Proses materi adalah jenis proses yang paling umum digunakan karena penelitian teks naratif siswa ini menunjukkan bahwa siswa harus menggunakan unsur kebahasaan dari teks naratif untuk memberikan informasi. Tujuan dari jenis teks dalam teks naratif siswa adalah untuk mendorong pembaca untuk membayangkan kata-kata dan pola kalimat yang digunakan dalam teks. Ini dapat membantu untuk naratif, siswa harus menggunakan makna khusus yang tepat, struktur generik, karakteristik linguistik, dan elemen bahasa untuk merangsang minat pembaca dalam memberikan informasi yang diperlukan sambil menghibur mereka.

\section{A B S T R A K}

Halliday. Temuan menunjukkan bahwa jenis proses yang dominan digunakan dalam

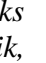


(Monbec, 2020; Ryshina-Pankova et al., 2021). When language is used to coordinate, recognize, and convey our world- and consciousness experiences, this is referred to as ideational meta-function. Experiential and Logical sub-functions are found in ideational metafunctions. The Experiential Meaning is mainly concerned with substance and ideas - the experience. The relationship between concepts is referred to as logical meaning. As an interpersonal metafunction, language is connected to language to urge us to interact with others in conversation, play roles, transmit and understand emotion, conduct, and viewpoints (Alshenqeeti, 2018; Maican \& Cocoradă, 2021; Mohammadi et al., 2020; Singh et al., 2020). Interpersonal meaning includes contact, indicating how our protective contribution evolves into and encodes beliefs about responsibility (Timmermans et al., 2019; Wonodipho, 2019).

The textual meta-function refers to the remainder of the text or other linguistic instances using vocabulary (Calil \& Myhill, 2020; Kutrovátz, 2022). Textual meta-function shows that the text may be organized utilizing languages. A specific type of structure provides an analysis of a clause in any function made up of several pieces. A meta-function analysis of a text can assist readers in comprehending the environment in which a text exists, namely how information is formed (Abbas et al., 2021; Huang \& Liang, 2021). The current research focused on the experiential significance of transitivity structure analysis and its application in narrative text. The ideational metafunction, which was especially experienced and improved by transitivity, was the focus of this study. This study's source of data came from narrative texts created by students in tenth-grade vocational high school. Several analyses of transitivity system approaches have been published in newspapers, speeches, debates, and songs. These studies looked at how Halliday's transitivity theory was used and the distributions, functions, and leading participants in transitivity processes. Transitivity analysis, a subnetwork of the ideational metafunction, investigates the content or experiential meaning (Fatinova et al., 2020; Pamungkas, 2018). It is a word for one part of grammar that organizes verb meanings depending on process types (Almuhammadi, 2020; Jean \& Simard, 2013; Tobing \& Pranowo, 2020). The term transitivity refers to the expression of a process that consists of doing, feeling, being, and taking actions that happen in social life. Language is used to communicate thoughts about specific people, objects, attributes, and the interrelationships of the world around us (Ahmad, 2018; Graus \& Coppen, 2015; Sik, 2015). The foundation of representation is transitivity, which is how the clause categorizes events and circumstances. Transitivity analysis interprets one of the clause's structural strands. In essential words, transitivity refers to the expression of a process that includes behaviors such as doing, feeling, being, and talking in social life. It can indicate who did the action, when it was performed, and what the step was performed. Several process categories are utilized to study the phrase intransitivity, including material, mental, behavioral, verbal, existential, and relational processes. These process types look at the sentence structure represented by processes and the participants and conditions surrounding them. People can deduce how the field of a situation is produced by evaluating the transitivity system (Banshchikova et al., 2015; Tjalla et al., 2017).

Language cannot be understood one at a time without considering contextual information about the current circumstances and culture (House et al., 2021; Klimova, 2021; Maican \& Cocoradă, 2021). As a result, language can only be understood when individuals comprehend the circumstance and culture. The context of a situation deals with the participant, the participant's activity, other significant characteristics of the circumstance, and the consequence of the spoken action (Prayogi \& Shobron, 2020; Singh et al., 2020). The context of a situation comprises three components: field, tenor, and mode, which combine to generate a meaning configuration. The research showed in the A clause is to be used to illustrate how a person is acting or by whom or to whom the action is taken, or for different forms of procedure and transit (Guswita \& Suhardi, 2020). The study summarized that transitivity is a significant aspect of the instruction of texts (Zhu Yujie, 2018). Through the transitivity study of the English language teaching, the researcher contributes to a better understanding of reading and the environment; The researcher also helps listeners learn the meaning of words.

Previous research conducted another research on the Transitivity Analysis of Framing in The Online News Articles (Suparto, 2018). The study's purpose showed that the analysis could identify the reader's positions on the positive or negative perception of the respondents in the texts by using the transitivity study, which analyses the text's structures, participants, and circumstances. Framing used to persuade the reader around an event can also be evaluated through a transitivity analysis, which helps people understand the content more objectively, specifically from the news. The research shows that the preference of language types is driven in every expression (Adjei et al., 2015). There are several ways that a writer may use language tools to convey the same concept or phenomenon in a text. In the creative process and the policy arena, literary authors and politicians select specific linguistic objects intentionally or unconsciously from others to reflect stylistic perceptions or incidents (Andrade et al., 2014; Schwarz \& Hamman-Ortiz, 2020; Voorhees \& Vorobel, 2021). Furthermore, other researchers studied the transitivity system in English department students' narrative texts (Zein et al., 2018). The purpose for their choice is because they have collected narrative text resources, and the method of teaching writing is genre-based. Other research is about a transitivity analysis of tenth-grade students' recount texts; the purpose of this research is to investigate the students' recount texts depending on the criteria and look into the students' writing errors (Senjawati, 2016). Those seven previous studies examined had 
similarities and variations between them. The similarity is that the previous study focused mainly on the interpretation of Halliday's transitivity principle. Nowadays, there is no study of transitivity analysis of students' narrative texts at vocational high schools majoring in Tourism. Besides, the research subjects in this study were the tenth-grade students majoring in Tourism Industry. The research discussed the significance of process types, the process types most usually applied in students' narrative texts, and circumstantial elements in vocational high school students' narrative texts to make this research effective. This study aimed at identifying the process types that characterize the students' narrative texts. As a result, the findings of this study can be used as a foundation for future research on a similar topic.

\section{METHOD}

The Narrative texts of tenth-grade students at SMKN 4 Denpasar were analyzed using the transitivity system. As defined previously, this research employed an analysis based on language's Ideational Metafunction, specifically Experiential Meaning in Systemic Functional Grammar. The field of the context may be discovered through the study of process types described through the transitivity system. The process types are described in transitivity analysis: material, mental, behavioral, verbal, existential, and relational processes. The participant feature research is essential to the process types since it conveys its participant functions. The descriptive qualitative technique was chosen as the strategy in this investigation. The participants in this study were tenthgrade students from SMKN 4 Denpasar, especially from class X Tata Boga. In addition, 28 students participated as research subjects for this study. The students in the tenth grade were chosen since a narrative text is required in the 2013 curriculum, and this type of literature was the focus of the research.

The researcher utilized text analysis to collect data. Students in tenth grade used the narrative texts as data collecting methods. The technique utilized to collect narrative texts was through students' worksheets. The instrument consisted of a collection of tables and data distribution sheets used to collect and analyze the data using the theories employed in this research. To achieve the study's goals, several hypotheses were used to analyze the data. The first was a study of the students' Narrative texts, which focused on their structure and linguistic structure. Schematic design for Narrative texts in students was used to assess the texts: orientation, complication, and resolution (Anderson, 1997). While studying the linguistic aspects of Narrative text, the researcher evaluated the texts using Gerot and Wignell's = grammatical structures. As a result, each sentence was examined using the transitivity system. The research was based on the Narrative texts of the students, which contained process types.

There is only one instrument that is used. The instrument was a table of data distribution sheet used to collect and analyze data using the theories employed in this study. The study's findings are intended to improve students' writing skills, allowing them to write in English correctly. It is also expected to provide teachers with attempts to enhance their writing skills. As a result, the data in this study can be used as a starting point for future research on a relevant topic. The instrument was a set of tables and data distribution sheets used to collect and analyze data based on the theories utilized in this study. Three tables made up the data distribution sheets. Data distribution sheets are classified in Table 1.

Table 1. Data Sheet Analysis of Process Types

\begin{tabular}{|c|c|c|c|c|c|c|c|c|c|c|c|}
\hline \multirow{4}{*}{ Subjects } & \multicolumn{11}{|c|}{ The Use of Process Types } \\
\hline & \multirow{3}{*}{ Mat } & \multirow{3}{*}{ Men } & \multirow{3}{*}{ Beh } & \multirow{3}{*}{ Ver } & \multirow{3}{*}{ Ext } & \multicolumn{6}{|c|}{ Relational } \\
\hline & & & & & & \multicolumn{3}{|c|}{ Attributive } & \multicolumn{3}{|c|}{ Identifying } \\
\hline & & & & & & Int & Poss & Circ & Int & Poss & Circ \\
\hline Student A & 9 & 2 & 4 & & 3 & 1 & 3 & & & 1 & \\
\hline Student B & 8 & 6 & 5 & 3 & 1 & & 1 & & & & \\
\hline Student C & 5 & 1 & 1 & & & & 1 & 1 & & & \\
\hline Student D & 5 & 2 & 3 & 1 & 1 & & 1 & 1 & & & \\
\hline Student E & 6 & & 6 & & 1 & 1 & & & & & \\
\hline Student F & 8 & 7 & 6 & 4 & 1 & 2 & & & & 1 & \\
\hline Student G & 8 & & 2 & & & & & & & & \\
\hline Student H & 18 & 3 & 6 & & & & 1 & & 1 & & \\
\hline Student I & 10 & 2 & 7 & 2 & 3 & 9 & & & & & \\
\hline Student J & 11 & 1 & 2 & 1 & & 2 & & & & & \\
\hline Student K & 17 & 2 & 6 & 4 & & 3 & & & 1 & & \\
\hline Student L & 8 & & 2 & 2 & & 3 & & & & & \\
\hline Student M & 12 & & 11 & 1 & & 2 & & & & & \\
\hline Student N & 17 & 2 & 3 & & & 1 & & & & & \\
\hline
\end{tabular}




\begin{tabular}{|c|c|c|c|c|c|c|c|c|c|c|c|}
\hline \multirow{4}{*}{ Subjects } & \multicolumn{11}{|c|}{ The Use of Process Types } \\
\hline & \multirow{3}{*}{ Mat } & \multirow{3}{*}{ Men } & \multirow{3}{*}{ Beh } & \multirow{3}{*}{ Ver } & \multirow{3}{*}{ Ext } & \multicolumn{6}{|c|}{ Relational } \\
\hline & & & & & & \multicolumn{3}{|c|}{ Attributive } & \multicolumn{3}{|c|}{ Identifying } \\
\hline & & & & & & Int & Poss & Circ & Int & Poss & Circ \\
\hline Student $\mathrm{O}$ & 18 & 1 & 5 & 1 & 1 & & & & & & \\
\hline Student $\mathrm{P}$ & 20 & & 8 & 2 & 3 & 4 & 1 & & & & \\
\hline Student Q & 9 & & 4 & 2 & & & & & & & \\
\hline Student R & 18 & 1 & 5 & 5 & 2 & 2 & & & & & \\
\hline Student S & 13 & 3 & 10 & 3 & 1 & 8 & & & & & \\
\hline Student $\mathrm{T}$ & 14 & & 4 & 3 & 1 & 1 & & & & & \\
\hline Student U & 15 & 2 & 6 & & 1 & 2 & & & & & \\
\hline Student V & 8 & 1 & 5 & 4 & & & & & & & \\
\hline Student W & 20 & & 2 & & & 1 & & & & & \\
\hline Student X & 10 & & 1 & & & 2 & & & & & \\
\hline Student Y & 19 & 1 & 6 & 3 & 1 & 6 & 1 & & & & \\
\hline Student Z & 16 & & 6 & 3 & 1 & 4 & 1 & & & & \\
\hline Student AA & 11 & & 11 & & & & 1 & 1 & & & \\
\hline Student AB & 5 & 1 & 2 & 2 & & & & & & & \\
\hline Total & 338 & 38 & 139 & 46 & 21 & 54 & 11 & 3 & 2 & 2 & $\mathbf{0}$ \\
\hline
\end{tabular}

To evaluate the data applied several hypotheses to reach the study's objectives. The first was a study of the students' Narrative texts, which covered the structure and linguistic characteristics of Narrative texts. The texts were evaluated using Anderson's stated schematic design for Narrative texts in students: orientation, complication, and resolution (Anderson, 1997). The researcher analyzed the texts based on the linguistic features constructed by Gerot and Wignell while studying the linguistic elements of Narrative text. The result was to analyze each sentence using the transitivity system. The study was based on the students' Narrative texts, which included process types. In conclusion, the transitivity analysis findings included the applications of a specific participant, material process, past tense, semantic meaning, and circumstances of place and time that were connected to Gerot \& Wignell criteria for Narrative texts. The second step was to investigate the process that students were faced. To analyze the difficulties of students, there was just one step.

\section{RESULT AND DISCUSSION}

\section{Result}

The data for this study obtained from narrative texts written by students in class X Tata Boga at SMKN 4 Denpasar. In this study, the narrative texts of 28 students were employed as data sources. To evaluate the writings in terms of the transitivity system, the researcher modified the students' original texts into sentence and clause modifications. Each sentence of the students' narrative texts was examined for components of the transitivity system, such as process types and participant functions. Material processes are actions and events that take place. They convey the idea that one thing performs something that other entities could do to other commodities. Participant Functions are divided into two categories. In the Material Process, they are both Actor and Goal. The actor provides the need or conducts the action, whereas the goal suffers or goes through the process. Besides the previously mentioned above, Material contains two more participants, called Range and Beneficiary. The scope is the term used to describe the range of a material process. The material process turns out 338 times in the students' narrative texts. Several material processes discovered are she (actor), gave (material), and the used bottle (goal). It can be revealed that 'she' as an actor, the verb 'gave' is a material process that refers to the activity carried out by the subject, the words 'the used bottle' are the goals. Mental process is a process that displays awareness, information, affection, and desire. Semantically, a mental process involves a human or a conscious being's inside sense. The psychological process is related. In the mental process, the sensor and phenomenon are two participants. Senser is a conscious participant. It must also be observed that only an aware (human) being would be used as a mental process sensor. The phenomenon is the participant, which the conscious sensor thought, felt, or perceives. The mental process turns out 38 times in the students' Narrative texts. Some findings of the mental process are asserted in Table 2.

Table 2. The Example of Mental Process Found in the Students' Narrative Texts

\begin{tabular}{|c|c|c|c|c|}
\hline Because & Mia & is & afraid & of cockroaches \\
\hline Circ: Cause: Reason & Senser & & Proc: Mental: Perception & Phenomenon \\
\hline
\end{tabular}


Table 2 represents a mental process in terms of perception. Based on that clause, the one who feels what is called a senser is 'Mia,' the word 'afraid' is the process of perceiving something, and the thing that is afraid is 'cockroaches,' which is called phenomenon. Behavioral process is the kind of process that exists between the material and the mental process. Consequently, the behavioral process is a physiological and mental activity process that involves activities that a conscious being should experience. Behavioral process only has one participant in a clause, called behaver. On occasions, a new participant shows specified behavior. This process type appears three times in the Narrative texts of the students. Several examples of behavioral processes discovered are discussed in Table 3.

Table 3. The Example of Behavioral Process Found in the Students' Narrative Texts

\begin{tabular}{|c|c|c|}
\hline Judy & was & disappointed \\
\hline Behaver & & Proc: Behavioral \\
\hline
\end{tabular}

Table 3 points out that the participant who behaves or is called behaver is 'Judy.' The word 'disappointed' is classified as a behavioral process because it involves instinctual expressions such as spontaneous physical and behavioral responses. The verbal process is the act of speaking. Verbal process has some mental process characteristics, particularly when we consider that verbalization of thoughts is a form of expression, verbal processes reflect information activities. The process includes saying such as telling, asking, talking, etc. The types of participants in verbal processes are Sayer, Receiver, and Verbiage. Often the participant is a conscious participant who expresses the speech process. But that is not generally the situation because anything that can send a signal can be a sayer. The benefit of a verbal message is the participant receiver. Verbal process discovered are described in Table 4.

Table 4. The Example of Verbal Process Found in the Students' Narrative Texts

\begin{tabular}{llll}
\hline And & his parents & reprimanded & him \\
\hline & Sayer & Proc: Verbal & Receiver \\
\hline
\end{tabular}

Table 4 represents that 'his parents' commits the action to 'him' that behave as a receiver. The content that is said or verbiage is 'reprimanded.' Besides, the one who is addressed the verbal process is 'him,' and it is classified as a receiver. Existential processes are human existence processes. This means something happens or exists. The existential process is a clause that addresses the life of an object with no predictions. There are two participants in an existential process, namely existential and the existent. Some findings of existential processes are asserted in Table 5.

Table 5. The Example of Existential Process Found in the Students' Narrative Texts

\begin{tabular}{lll}
\hline There & were & no large dogs \\
\hline & Proc: Existential & Existent \\
\hline
\end{tabular}

Based on Table 5, the term 'were' denotes that something existed. As a result, 'were' may be considered to be a part of the existential process. Furthermore, the item that exists is 'no large dogs,' allowing it to be classified as existent.bThe term 'there' is used in a sentence in the existential process. Other terms like exist, remain, occur, come about, take place, follow, sit, and grow can also describe this process. The word 'there' is not evaluated for Transitivity in this procedure since it has no figurative meaning. Relational processes are described as processes that come under two principal categories: attributive relational processes and identifying relational processes. It may be defined as intensive, circumstantial, and possessive. The concepts of being and having been included in the relational process. There are five types of relational processes that identify the students' Narrative texts, such as intensive attributive process, possessive attributive process, circumstantial attributive process, intensive identifying process, and possessive identifying process. Several examples of relational approaches found are presented in Table 6, Table 7, Table 8, Table and Table 9.

Table 6. The Example of Intensive Attributive Process Found in the Students' Narrative Texts

\begin{tabular}{lll}
\hline Judy & was & a dog lover \\
\hline Carrier & Proc: Att: Intensive & Attribute \\
\hline
\end{tabular}

Table 6 indicates the relational process, an incredibly intensive attributive process because it is concerned with the connection of two things in which the construction 'Judy' is described as a dog lover, and it is 
classified as a carrier. The word 'was' is an intensive attributive process that relates carrier to attribute. Besides, the word 'a dog lover' is categorized as an attribute.

Table 7. The Example of Possessive Attributive Process Found in the Students' Narrative Texts

\begin{tabular}{|c|c|c|c|}
\hline The grocer & on the other hand, only & Had & little dogs \\
\hline Carrier & Circ: Loc: Place & Proc: Att: Poss & Attribute \\
\hline
\end{tabular}

Table 7 shows the relational process, particularly the possessive attributive process, since that clause classifies ownership of an object. The carrier in that clause is 'the grocer' that acts as the owner of an object. The word 'had' is categorized as a possessive attributive process. Moreover, the attribute which is called possessed is 'little dogs.' In Table 8, there is one circumstantial element; the phrase "in Japan" is classified as a place because it relates to a specific location.

Table 8. The Example of Circumstantial Attributive Process Found in the Students' Narrative Texts

\begin{tabular}{lll}
\hline Roro Jongrang statue & is & located within Candi Prambana \\
\hline Carrier & Proc: Att: Circumstantial & Attribute \\
\hline
\end{tabular}

Table 8 shows that the word 'is' represents the circumstantial attributive process. It can be seen from the phrase 'Roro Jongrang statue' is a carrier, and 'located within Candi Prambanan' is an attribute that describes the object in terms of place.

Table 9. The Example of Intensive Identifying Process Found in the Students' Narrative Texts

\begin{tabular}{lll}
\hline Monkey & Are & terrific imitators \\
\hline Token & Proc: Identifying: Intensive & Value \\
\hline
\end{tabular}

Table 9 shows that 'Monkey' is a token. It is an object that is defined. The word 'are' is classified as an intensive identifying process since it establishes the equality relation of the participants. The value of that clause is 'terrific imitators' because it is a thing that defines the object.

Table 10. The Example of Possessive Identifying Process Found in the Students' Narrative Texts

\begin{tabular}{cccc}
\hline She & Did Not & Have & Many Friends \\
\hline Token & & Proc: Identifying: Circumstantial & Value \\
\hline
\end{tabular}

The process type in Table 10 is categorized as a possessive identifying process since that clause classifies ownership of an object precisely. The token in that clause is 'she,' which acts as the owner of an object. The word 'have' is categorized as a possessive identifying process. Moreover, the identifying which is called possessed is 'many friends.. In addition, Table 11 counted the process types identified in the students' Narrative texts to determine which process types are most commonly used in the students' Narrative texts. The entire application of process types specified can be seen in Table 11

Table 11. Total Usage of Process Types Used in the Students' Narrative Texts

\begin{tabular}{clcc}
\hline No & \multicolumn{1}{c}{ Process Types } & Frequency of Occurrence & Percentage (\%) \\
\hline 1 & Material Process & 338 & $51,68 \%$ \\
2 & Behavioral Process & 139 & $21,25 \%$ \\
3 & Intensive Attributive Process & 55 & $8,41 \%$ \\
4 & Verbal Process & 46 & $7,03 \%$ \\
5 & Mental Process & 38 & $5,81 \%$ \\
6 & Existential Process & 20 & $3,06 \%$ \\
7 & Possessive Attributive Process & 11 & $1,68 \%$ \\
8 & Circumstantial Attributive Process & 3 & $0,46 \%$ \\
9 & Intensive Identifying Process & 2 & $0,31 \%$ \\
10 & Possessive Identifying Process & 2 & $0,31 \%$ \\
11 & Circumstantial Identifying Process & 0 & $0,00 \%$ \\
\hline \multicolumn{2}{r}{ Total } & $\mathbf{6 5 4}$ & $\mathbf{1 0 0 \%}$ \\
\hline
\end{tabular}


Based on the analysis results in Table 11, the first dominantly used process typically found in the students' Narrative texts is a material process with the frequency of occurrence of $338(51,68 \%)$. It typically refers to the subjects' acts in narrative text. Subsequently, the second most frequent process type is the behavioral process, which appears 139 times $(21,25 \%)$. The dominant process type in third place is an intensive attributive process. Many clauses in this process showed the participants' similar connections. The dominant process type occupying the fourth position is the verbal process because presenting something to the speakers happens 46 times $(7,03 \%)$ in the students' Narrative texts. The mental process occupies the fifth position of the dominant process types. In the students' narrative text, the students discovered mental processes connected to perception, affection, cognition, and volition processes, with the frequency of occurrence of 35 times (3.75\%). Furthermore, the existential process occupies the sixth position of the dominant process types since the students' Narrative texts contain the process of something that happens or exists, and it appears 20 times (3.06\%) in the students' Narrative texts. Moreover, the less process is a possessive attributive process which respectively occurs 11 times $(1,68 \%)$, The process types that are not dominantly used are the circumstantial attributive process which respectively occurs 3 times $(0,46 \%)$, intensive identifying, and possessive identifying process, respectively 2 times $(0,31 \%)$ of the occurrence rate. In connecting to these activities, the students' narrative texts categorized the ownership of an object and mainly described the participants' equality.

\section{Discussion}

The narrative texts were written by students who were not native English speakers. As a result, there was a potential for the students' irregularities from their texts because there was no expert checking process, as there was in the sonnets or speech campaign, which went through many stages of verifying the text before being released to the public. Since Indonesian students could write English texts, they still made errors such as using the to-infinitive, past tense, preposition, sentence structure, plurality, and article (Senjawati, 2016; Zein et al., 2018). As a result, after evaluating the students' narrative texts, all students in class $X$ at SMKN 4 Denpasar corrected the weak points and problems in their texts. It also seeks to provide students with deeper knowledge. The pupils conveyed several ideas in their texts. In narrative texts, the majority of the phrases produced by the pupils were in terms of material processes (Netolicky \& Barnes, 2018; Suhandra, 2018). Because the students' representations of their imaginations in their reading and listening experiences showed that they understand the social function of a narrative text that tells a past event using the material process in their texts. After the material process comes to the behavioral process, the second most common process type in students' narrative writings. During this procedure, the students' narrative texts depicted a variety of physiological and psychological behaviors (usually human) (Bertram et al., 2021; Jiang et al., 2019). They are in the middle of mental and physical processes. The third most common step in the students' narrative texts is the intensive attributive process. The students' Narrative writings described several relationships between two items during this level. Myth, legend, and fable were the topics of the narrative writings. Furthermore, in Jokowi's speech campaign, another research analysis was alarming (Guswita \& Suhardi, 2020). There are several explanations in Jokowi's speech on the relationship between his participating role. Their research discovered that Jokowi employed the relational process to identify, explain, and classify his thought.

The verbal process is the fourth most common process type. Because students liked to mention what they talked about with others, verbal processes may often appear in a narrative work (Enke et al., 2022). As a result, the application of the verbal process develops an opinion that supports the writer's concept to criticize Indonesian legislation, such as in this sentence, The Indonesian Legal Aid Foundation has pushed for the repeal of discriminatory laws owing to the harm it does to the country's minority faiths (Suparto, 2018). In fifth place, the mental process is the most common process type. When applying this technique, mental processes often involve at least one human person who has the mind in which the process happens (Biard et al., 2018; Enke et al., 2022). Perception, love, and intellect are all human senses that they integrate. The absence of material process appearance in a narrative text created by their student makes it harder for readers to grasp what the participants did (Wannagat et al., 2020, 2021; Wu et al., 2020). The idea is that using dominating material processes makes it easier for readers to comprehend what is going on. Mental processes to encode mental reactions such as perception, thoughts, and sentiments in his research on transitivity in political discourse (Bates, 2019; Enke et al., 2022). These mechanisms provide information about Mills' consciousness and how he perceives reality. To conclude, depending on the topic discussed in a single text, one process type may dominate the others. Students who were not native English speakers wrote the narrative texts. Because there was no expert checking method, there was a possibility for the students' mistakes in their texts, as there was in the sonnets or speech campaign, which went through several steps of checking before being given to the public. While Indonesian students could write English texts, they made mistakes such as employing the to-infinitive, past tense, preposition, sentence structure, plurality, and article (Senjawati, 2016; Zein et al., 2018). After evaluating the students' narrative texts, all students in class X at SMKN 4 Denpasar fixed the weak areas and flaws in their works. It also helps to offer pupils more in-depth information. 
According to the findings, most students have a conceptual understanding of the features and linguistic parts of a narrative text. However, when it comes to creating narrative texts, many pupils deviate from the norm. The students ' narrative texts recognized past tense, spellings, capital letters, plurality, object pronoun, preposition, quantifier, and preposition. Finally, the findings in this study of the students' narrative texts demonstrate that the students must use the linguistic elements of a narrative text to give information. The purpose of text types in students'. Narrative texts is to encourage readers to imagine the words and sentence patterns used in the texts. There are several meanings to one English word. Readers may easily recognize the content of the text by selecting the appropriate words in sentence context. Proper grammar in students' narrative texts might present readers with much information (Almuhammadi, 2020; Jean \& Simard, 2013; Uysal \& Yavuz, 2015). Furthermore, it may help to minimize misunderstandings about the contents of the narrative text. As a result, while creating a narrative text, writers must employ the proper specific meaning, generic structure, linguistic characteristics, and language elements to stimulate readers' interest in providing necessary information while entertaining them.

\section{CONCLUSION}

Students in SMKN 4 Denpasar's tenth grade should be encouraged to improve their English writing skills, particularly in narrative texts, because functions in the students' narrative texts could provide more information and entertain readers. The importance of language components used in the students' narrative texts also stimulates readers to imagine the words and sentence structures constructed in the texts. As a result, correct grammar in students' narrative texts could convey much information to readers.

\section{REFERENCES}

Abbas, H., Janjua, F., Masood, A., Rashid, I., \& Khan, M. M. Z. M. (2021). Textual analysis of traitorbased dataset through semi supervised machine learning. Future Generation Computer Systems, 125. https://doi.org/10.1016/j.future.2021.06.036.

Adjei, A. A., Ewusi-Mensah, L., \& Okoh, H. (2015). Transitivity in Political Discourse - A Study of the Major Process Types in the 2009 State-of-the-Nation Address in Ghana. Journal of Literature, Languages and Linguistics.

Ahmad, I. (2018). Teacher Cognition and Grammar Teaching in the Saudi Arabian Context. English Language Teaching, 11(12), 45-57. https://doi.org/10.5539/elt.v11n12p45.

Almuhammadi, A. (2020). Teaching Grammar : Professional Needs of Saudi EFL Instructors. International Journal of English Linguistics, 10(3), 14-20. https://doi.org/10.5539/ijel.v10n3p14.

Alshenqeeti, H. (2018). Motivation and Foreign Language Learning: Exploring the Rise of Motivation Strategies in the EFL Classroom. International Journal of Applied Linguistics and English Literature, 7(7), 1. https://doi.org/10.7575/aiac.ijalel.v.7n.7p.1.

Anderson. (1997). Text Types in English 1 \& 2. McMillan Education.

Andrade, M. S., Evans, N. W., \& Hartshorn, K. J. (2014). Linguistic support for non-native English speakers: Higher education practices in the United States. Journal of Student Affairs Research and Practice, 51(2). https://doi.org/10.1515/jsarp-2014-0020.

Banks, D. (2010). The interpersonal metafunction in French from a Systemic Functional perspective. Language Sciences, 32(3). https://doi.org/10.1016/j.langsci.2009.06.002.

Banshchikova, T., Solomonov, V., \& Fomina, E. (2015). Attitudes and Tolerance in the Structure of Individual Readiness for Intercultural Interaction. Procedia - Social and Behavioral Sciences, 214. https://doi.org/10.1016/j.sbspro.2015.11.753.

Bates, A. (2019). Character education and the 'priority of recognition.' Cambridge Journal of Education, 49(6), 695-710. https://doi.org/10.1080/0305764X.2019.1590529.

Becker, W. (2020). Metafunctions for benchmarking in sensitivity analysis. Reliability Engineering \& System Safety, 204. https://doi.org/10.1016/j.ress.2020.107189.

Belligh, T., \& Willems, K. (2021). What's in a code? The code-inference distinction in Neo-Gricean Pragmatics, Relevance Theory, and Integral Linguistics. Language Sciences, 83. https://doi.org/10.1016/j.langsci.2020.101310.

Bertram, C., Weiss, Z., Zachrich, L., \& Ziai, R. (2021). Artificial intelligence in history education. Linguistic content and complexity analyses of student writings in the CAHisT project (Computational assessment of historical thinking). Computers and Education: Artificial Intelligence. https://doi.org/10.1016/j.caeai.2021.100038.

Biard, N., Cojean, S., \& Jamet, E. (2018). Effects of Segmentation and Pacing on Procedural Learning By Video. Computers in Human Behavior, 89, 411-417. https://doi.org/10.1016/j.chb.2017.12.002. 
Brisk, M. E., Tian, Z., \& Ballard, E. (2021). Autobiography writing instruction: The journey of a teacher participating in a systemic functional linguistics genre pedagogy professional development. System, 97. https://doi.org/10.1016/j.system.2020.102429.

Calil, E., \& Myhill, D. (2020). Dialogue, erasure and spontaneous comments during textual composition: What students' metalinguistic talk reveals about newly-literate writers' understanding of revision. Linguistics and Education, 60. https://doi.org/10.1016/j.linged.2020.100875.

Enke, S., Gunzenhauser, C., Hepach, R., Karbach, J., \& Saalbach, H. (2022). Differences in cognitive processing? The role of verbal processes and mental effort in bilingual and monolingual children's planning performance. Journal of Experimental Child Psychology, 213. https://doi.org/10.1016/j.jecp.2021.105255.

Farsani, M. A., Jamali, H. R., Beikmohammadi, M., Ghorbani, B., \& Daneshvar, L. S. (2021). Methodological orientations, academic citations, and scientific collaboration in applied linguistics: What do research synthesis and bibliometrics indicate? System, 100. https://doi.org/10.1016/j.system.2021.102547.

Fatinova, D., Mubarok, Y., \& Emha, R. J. (2020). Representasi LGBT dalam Perspektif Ideologi Khilafah: Kajian Transitivitas dalam Buletin Kaffah. Buletin Al-Turas, 25(2). https://doi.org/10.15408/bat.v25i2.13161.

Graus, J., \& Coppen, P.-A. (2015). Student teacher beliefs on grammar instruction. Language Teaching Research. https://doi.org/10.1177/1362168815603237.

Guswita, K. A., \& Suhardi, S. (2020). Transitivity Analysis of Jokowi and Prabowo Campaign Speech in Indonesian Presidential Election 2019. Indonesia Journal of EFL and Linguistic, 5(1). https://doi.org/10.21462/ijefl.v5i1.234.

House, J., Kádár, D. Z., Liu, F., \& Bi, Z. (2021). Altered speech act indication: A problem for foreign language learners? System, 101. https://doi.org/10.1016/j.system.2021.102554.

Huang, G., \& Liang, H. (2021). Uncovering the effects of textual features on trustworthiness of online consumer reviews: A computational-experimental approach. Journal of Business Research, 126. https://doi.org/10.1016/j.jbusres.2020.12.052.

Jean, G., \& Simard, D. (2013). Deductive versus inductive grammar instruction: Investigating possible relationships between gains, preferences and learning styles. System, 41(4). https://doi.org/10.1016/j.system.2013.10.008.

Jiang, J., Bi, P., \& Liu, H. (2019). Syntactic complexity development in the writings of EFL learners: Insights from a dependency syntactically-annotated corpus. Journal of Second Language Writing, 46. https://doi.org/10.1016/j.jslw.2019.100666.

Kleinke, S. (2010). Speaker activity and Grice's maxims of conversation at the interface of Pragmatics and Cognitive Linguistics. Journal of Pragmatics, 42. https://doi.org/10.1016/j.pragma.2010.05.008.

Klimova, B. (2021). ScienceDirect An Insight into Online Foreign Language Learning and Teaching in the Era of COVID-19 Pandemic. Procedia Computer Science, 192, 1787-1794. https://doi.org/10.1016/j.procs.2021.08.183.

Kutrovátz, G. (2022). Anatomical identifications of stars: Textual descriptions in Ptolemy's star catalogue. Studies in History and Philosophy of Science Part A, 91. https://doi.org/10.1016/j.shpsa.2021.11.012.

Maican, M. A., \& Cocoradă, E. (2021). Online foreign language learning in higher education and its correlates during the covid-19 pandemic. Sustainability (Switzerland), 13(2), 1-21. https://doi.org/10.3390/su13020781.

Mohammadi, M., Moenikia, M., \& Zahed-Babelan, A. (2020). The role of advance organizer on English language learning as a second language. Procedia - Social and Behavioral Sciences, 2(2). https://doi.org/10.1016/j.sbspro.2010.03.747.

Monbec, L. (2020). Systemic Functional Linguistics for the EGAP module: Revisiting the common core. Journal of English for Academic Purposes, 43. https://doi.org/10.1016/j.jeap.2019.100794.

Netolicky, D. M., \& Barnes, N. (2018). Method as a journey: a narrative dialogic partnership illuminating decision-making in qualitative educational research. International Journal of Research \& Method in Education, 41(5). https://doi.org/10.1080/1743727X.2017.1295938.

Pamungkas, W. R. (2018). Ketransitifan Dalam Teks-Teks Di Dunia Maya: Perspektif Linguistik Sistemik Fungsional. BASINDO: Jurnal Kajian Bahasa, Sastra Indonesia, Dan Pembelajarannya, 2(2). https://doi.org/10.17977/um007v2i22018p157.

Pietrandrea, P. (2012). The conceptual structure of irreality: a focus on non-exclusion-of-factuality as a conceptual and a linguistic category. Language Sciences, 34(2). https://doi.org/10.1016/j.langsci.2011.08.004. 
Prayogi, R. D., \& Shobron, S. (2020). Arabic as Second Language of Educated Generation. Ittishal Educational Research Journal, 1(1). https://doi.org/10.51425/ierj.v1i1.2.

Reed, Y. (2019). Countering linguistic imperialism with stories in the languages of africa: The african storybook initiative as a model for enabling in and out of school literacies. South African Journal of Childhood Education, 9(1), 1-8. https://doi.org/10.4102/sajce.v9i1.637.

Ryshina-Pankova, M., Barthold, W., \& Barthold, E. (2021). Enhancing the content- and languageintegrated multiple literacies framework: Systemic functional linguistics for teaching regional diversity. System, 96. https://doi.org/10.1016/j.system.2020.102403.

Schwarz, V. S., \& Hamman-Ortiz, L. (2020). Systemic functional linguistics, teacher education, and writing outcomes for U.S. elementary English learners: A review of the literature. Journal of Second Language Writing, 49. https://doi.org/10.1016/j.jslw.2020.100727.

Senjawati, D. (2016). transitivity analysis of tenth-grade students' recount texts. E-Journal on English Education, 4(1).

Sik, K. (2015). Tradition or Modernism in Grammar Teaching: Deductive vs. Inductive Approaches. Procedia - Social and Behavioral Sciences, 197. https://doi.org/10.1016/j.sbspro.2015.07.340.

Singh, C. K. S., Singh, T. S. M., Abdullah, N. Y., Moneyam, S., Ismail, M. R., Tek, E., Karupayah, T., Chenderan, K., Singh, M. K. R., \& Singh, J. K. S. (2020). Rethinking English language teaching through Telegram, Whatsapp, Google classroom and Zoom. Systematic Reviews in Pharmacy, 11(11), 45-54. https://doi.org/10.31838/srp.2020.11.9.

Steiner, E. (2018). A tribute to M.A.K. Halliday. Lingua, 216. https://doi.org/10.1016/j.lingua.2018.10.009.

Suhandra, I. R. (2018). Pemanfaatan media gambar berseri untuk memperkaya kemampuan menulis naratif bahasa inggris siswa kelas IX MTS NW Nurul Wathon Pengembur Lombok Tengah. TRANSFORMASI: Jurnal Pengabdian https://doi.org/10.20414/transformasi.v14i1.576.

Suparto, A. D. (2018). Transitivity Analysis on Framing in The Online News Articles. Petra Christian University. Ranah Jurnal Kajian Bahasa, 7(1). https://doi.org/10.26499/rnh.v7i1.586.

Timmermans, A. C., Werf, M. P. C. G. van der, \& Rubie-Davies, C. M. (2019). The interpersonal character of teacher expectations: The perceived teacher-student relationship as an antecedent of teachers' track recommendations. Journal of School Psychology, 73. https://doi.org/10.1016/j.jsp.2019.02.004.

Tjalla, M., Akil, M., Hamra, A., \& Haryanto. (2017). The analysis of EFL students' needs for writing materials development. International Journal of Science and Research, 6(8), 313-317. https://doi.org/10.21275/ART20175922.

Tobing, R. L., \& Pranowo. (2020). Blended learning in French intermediate grammar learning: Is it effective? Cakrawala Pendidikan, 39(3). https://doi.org/10.21831/cp.v39i3.32035.

Tsepilova, A. V., \& Mikhaleva, L. V. (2015). Working with Formulaic Language as a Way to Evaluate and Improve EFL Non-linguistics Students' Pragmatic Skills in a Culture-specific Contextual Situation. Procedia - Social and Behavioral Sciences, 22. https://doi.org/10.1016/j.sbspro.2015.08.022.

Uysal, N. D., \& Yavuz, F. (2015). Pre-Service Teachers' Attitudes Towards Grammar Teaching. Procedia - Social and Behavioral Sciences, 191. https://doi.org/10.1016/j.sbspro.2015.04.353.

Voorhees, T. T., \& Vorobel, O. (2021). Integrating Qualitative Research into the Community College Linguistics Course: An Autoethnographic Inquiry. International Journal of Educational Research Open, 2. https://doi.org/10.1016/j.ijedro.2021.100053.

Wannagat, W., Henkel, M., \& Nieding, G. (2020). Children's comprehension of narrative texts: Protagonists' goals and mental representation of coherence relations. Cognitive Development, 56. https://doi.org/10.1016/j.cogdev.2020.100966.

Wannagat, W., Steinicke, V., Tibken, C., \& Nieding, G. (2021). Same topic, different genre: Elementary school children's mental representations of information embedded in narrative and expository texts. Learning and Instruction, 4. https://doi.org/10.1016/j.learninstruc.2021.101559.

Wonodipho, A. R. (2019). Establishing Interpersonal Communication And Organizational Climate To Improve Work Motivation. Jurnal Kepemimpinan Pendidikan, 2(1). https://doi.org/10.22236/jkpuhamka.v2i1.3816.

Zein, T. T., Sinar, T. S., Nurlela, N., \& Yusuf, M. (2018). Process Types of Transitivity System in English Department Students' Narrative Texts. Atlantis Press, 276. https://doi.org/10.2991/icoelt18.2019.21.

Zhu Yujie, L. F. (2018). Transitivity Analysis of American President Donald Trump's Inaugural Address. International Journal of Literature and Arts, 6. https://doi.org/10.11648/j.ijla.20180602.11. 